\title{
COMBINED TREATMENT WITH BEVACIZUMAB AND TRIAMCINOLONE ACETONIDE FOR MACULAR EDEMA DUE TO RETINAL VEIN OCCLUSION
}

\author{
Maja Vinkovićic, ${ }^{1,2}$ Damir Bosnar ${ }^{1,3}$, Eugenia Tedeschi Reiner ${ }^{1,4}$, \\ Gabriella De Salvo ${ }^{5}$ and Suzana Matić ${ }^{1,2}$
}

\begin{abstract}
${ }^{1}$ Josip Juraj Strossmayer University of Osijek, Faculty of Medicine, Osijek, Croatia;
${ }^{2}$ Department of Ophthalmology, Osijek University Hospital Centre, Osijek, Croatia; ${ }^{3}$ Department of Ophthalmology, Sveti Duh University Hospital, Zagreb; Josip Juraj Strossmayer University of Osijek, Faculty of Medicine, Osijek, Croatia;

${ }^{4}$ Department of Ophthalmology, Sestre milosrdnice University Hospital Centre, Zagreb, Croatia; ${ }^{5}$ Department of Ophthalmology, Southampton University Hospital, Southampton, United Kingdom
\end{abstract}

SUMMARY - The purpose of this study was to determine the efficacy of combined intravitreal bevacizumab and triamcinolone in the treatment of macular edema due to retinal vein occlusion. A prospective randomized trial was conducted in the Department of Ophthalmology, Osijek University Hospital Centre in Osijek including 51 patients divided into three groups depending on the drug received. The first group received $1.25 \mathrm{mg}$ intravitreal bevacizumab, the second group received $1 \mathrm{mg}$ intravitreal triamcinolone, and the third group received a combination of $1.25 \mathrm{mg}$ bevacizumab and 1 $\mathrm{mg}$ intravitreal triamcinolone on the same day. Changes in the central macular thickness, intraocular pressure and visual acuity were monitored during the follow up period. The retinal perfusion status was evaluated by fluorescein angiography. The group that received combined treatment had better outcome in terms of reduction of macular thickness. There was no statistically significant intraocular pressure elevation among the three treatment groups or within each group of patients. A positive trend regarding visual improvement was observed in the group receiving combined treatment in spite of the lowest initial visual acuity, highest value of macular thickness and longest mean duration of symptoms. In conclusion, combined treatment with bevacizumab and triamcinolone for the treatment of retinal vein occlusion is more potent, safe, efficient and cost-effective. It can also be recommended because fewer injections are needed in patients undergoing treatment for macular edema.

Key words: Retinal vein occlusion; Macular edema; Intravitreal application; Triamcinolone; Bevacizumab

\section{Introduction}

Retinal vein occlusion (RVO) is the second most common vascular retinal disorder and one of the leading causes of visual loss in the elderly. The incidence varies from $0.2 \%$ to $0.8 \% \%^{1,2}$. Current treatment options

Correspondence to: Maja Vinković, MD, Department of Ophthalmology, Osijek University Hospital Centre, Europska avenija 1416, HR-31000 Osijek, Croatia

E-mail: majavinkovic77@gmail.com

Received January 27, 2017, accepted January 9, 2018 for macular edema do not provide permanent solution due to frequent recurrence and persistence of the ede$\mathrm{ma}^{3}$. Monotherapy with intravitreal anti-vascular endothelial growth factor (anti-VEGF) agents or corticosteroids has its limitations and side effects, i.e. short duration, the need for repetitive injections, risk of endophthalmitis, rise of intraocular pressure (IOP), and cataract formation ${ }^{4-6}$. In the reference books there are only a few studies regarding simultaneous application of bevacizumab and triamcinolone for the treatment of macular edema following RVO. Ehrlich et al. ${ }^{7}$ used a 
higher dose of intravitreal corticosteroid (2 mg) although a dose of $1 \mathrm{mg}$ showed efficacy, with better safety profile and lower incidence of complications ${ }^{8}$. The main focus of this study was to determine the efficacy and safety of a combination of bevacizumab and triamcinolone for the treatment of macular edema due to RVO.

\section{Patients and Methods}

Fifty-one patients with macular edema secondary to RVO were enrolled in this prospective study, out of which 30 (59\%) women and 21 (41\%) men, mean age 70 (range 44-87) years. Informed consent was obtained from each participant after detailed explanation of the nature and possible consequences of the study. The research was approved by the institutional Review Board of the Osijek University Hospital Centre. The study followed the tenets of the Declaration of Helsinki.

At baseline, each patient underwent complete ophthalmologic examination including best corrected visual acuity (VA), biomicroscopic examination, applanation tonometry, indirect ophthalmoscopy, fluorescein angiography, and spectral domain optical coherence tomography (SD-OCT). These tests were repeated after intravitreal application of the drugs and at follow up visits after three, six and twelve months. According to the type of occlusion, 19 (37\%) patients had central retinal vein occlusion (CRVO) and $32(63 \%)$ patients had branch retinal vein occlusion (BRVO). They were randomly distributed to the drug they received. The type of occlusion was not a determining criterion for allocation to a specific group. Types of occlusion according to groups are shown in Figure 1.

Patients were classified into three groups. The first group received $1.25 \mathrm{mg}$ bevacizumab (group B), the second group received $1 \mathrm{mg}$ triamcinolone (group T), and the third group received intravitreal combination of both drugs (group BT) (1.25 mg bevacizumab and $1 \mathrm{mg}$ triamcinolone). The drug was administered in the operating room under aseptic conditions and after instillation of topical anesthetic (tetracaine $0.5 \%$ solution). The site of application was 3-4 $\mathrm{mm}$ from the limbus in the lower temporal quadrant, depending on the phakic status of the eye. Two different syringes were used in the combination treatment group, one for each drug. Depending on the central macular thick-

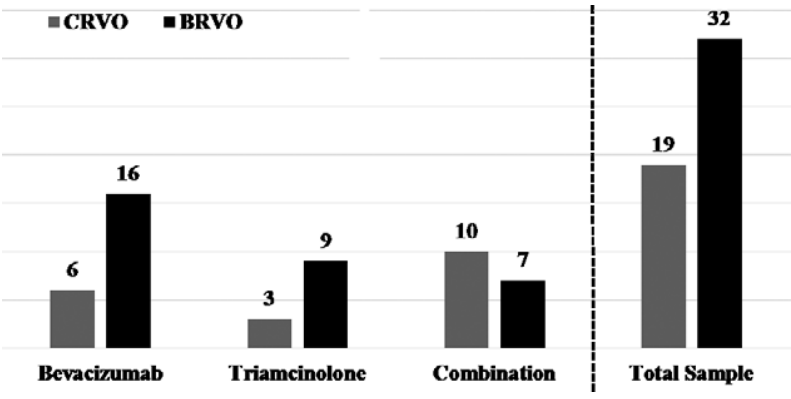

Fig. 1. Types of occlusion in patient groups.

$\mathrm{CRVO}=$ central retinal vein occlusion; $\mathrm{BRVO}=$ branch retinal vein occlusion

Table 1. Ischemic and non-ischemic types of occlusion according to therapy groups

\begin{tabular}{|l|l|l|l|}
\hline Group & Ischemic & Non-ischemic & Total \\
\hline Bevacizumab & 1 & 21 & 22 \\
Triamcinolone & 3 & 9 & 12 \\
Combination & 7 & 10 & 17 \\
Total & 11 & 40 & 51 \\
\hline
\end{tabular}

ness (CMT) measured on SD-OCT (CMT $\geq 250 \mu \mathrm{m})$ and the clinical finding on the fundus (residual exudation), patients were scheduled for reapplication of the drug. The interval between the applications was at least 6 weeks for bevacizumab and 12 weeks for triamcinolone. The average monitoring period per patient was 11 ( $\mathrm{SD} \pm 2$ ) months with a minimum of 3 visits, due to sample dissipation.

Data were analyzed by descriptive statistics and after determining distribution of the variables with Kolmogorov Smirnov test, nonparametric tests were used (Mann-Whitney U-test, Kruskal-Wallis, median test, Kendall's W-test, Cochran's Q-test). The final sample encompassed the patients who had minimally three visits, i.e. three measurements. The study was conducted on three independent samples and therefore the tests appropriate for independent samples were used. Statistical analysis was performed by using commercially available SPSS. The $\mathrm{p}$ value of 0.05 was selected to determine significance of the results.

\section{Results}

The efficacy of the drug was measured primarily by CMT change, while the increase in IOP reflected the safety of treatment. The change in VA was also as- 


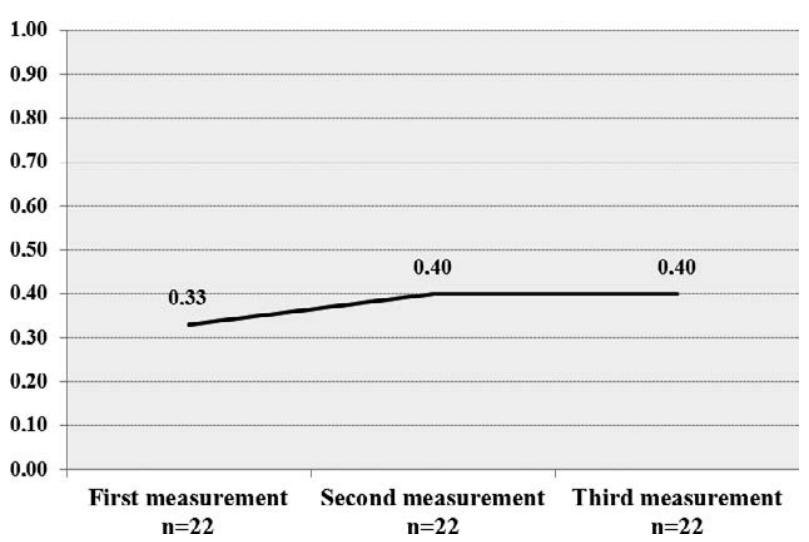

Fig. 2. Visual acuity changes (Snellen visual acuity) in bevacizumab group.

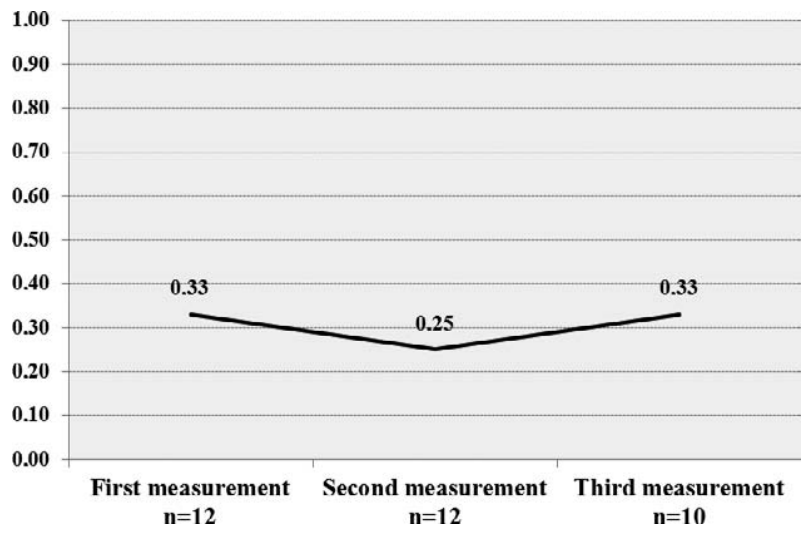

Fig. 3. Visual acuity changes (Snellen visual acuity) in triamcinolone group.

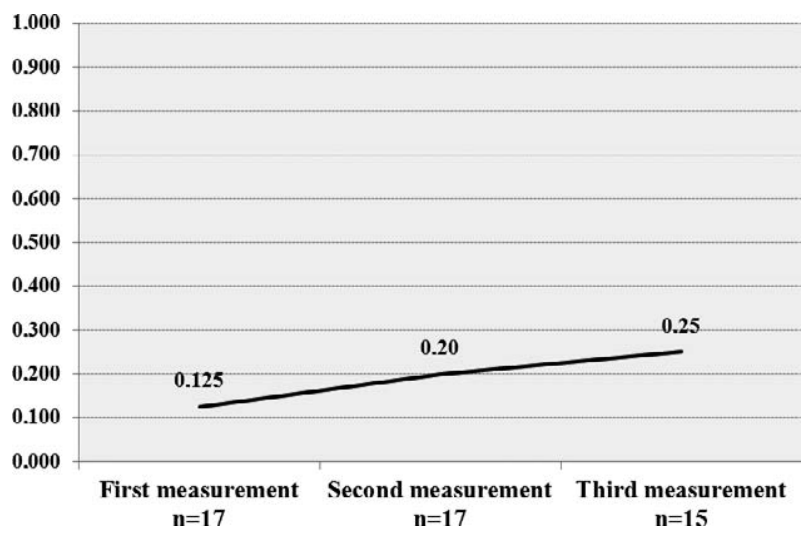

Fig. 4. Visual acuity changes (Snellen visual acuity) in bevacizumab plus triamcinolone group.

sessed as a secondary outcome. There was no statistically significant difference in age and sex among the groups (independent median test, $\mathrm{p}=0.656$; Kruskal-
@ Better VA Equal VA $\quad$ Worse VA

Combination

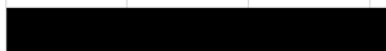

Triamcinolone

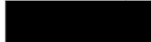

Bevacizumab

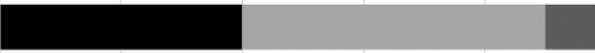

$\begin{array}{llllll}0 \% & 20 \% & 40 \% & 60 \% & 80 \% & 100 \%\end{array}$

Fig. 5. Qualitative shift in visual acuity between first and third visit.

$\mathrm{VA}=$ visual acuity

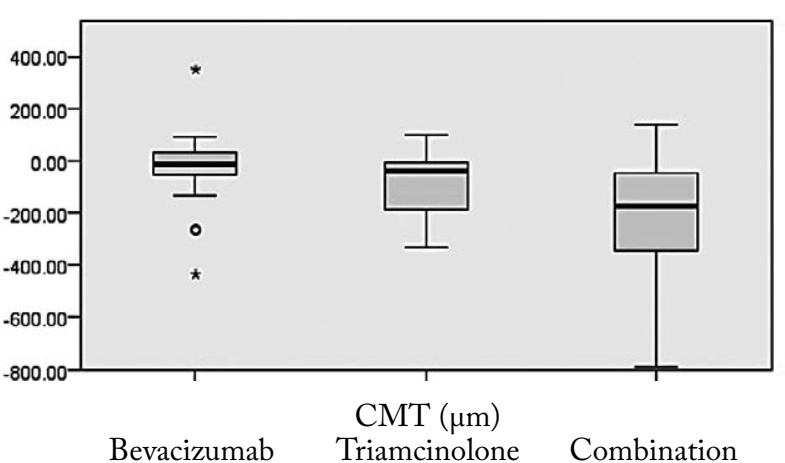

Fig. 6. Change in central macular thickness (CMT) across three patient groups.

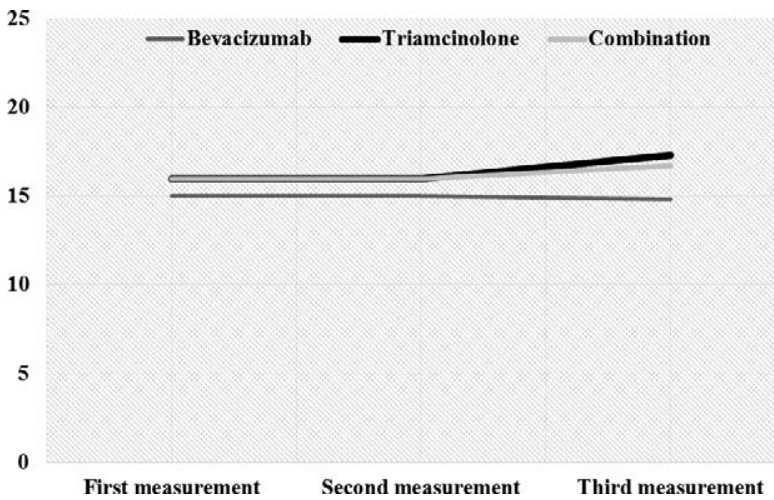

Fig. 7. Comparison of mean intraocular pressure values (mm Hg) among groups.

Wallis test for independent samples, $\mathrm{p}=0.758$ ). The type of occlusion did not influence distribution of the CMT change throughout measurements on the whole sample. It did not affect final VA $(\mathrm{p}=0.182), \mathrm{CMT}$ $(p=0.555)$ or IOP changes $(p=0.060)$ either. The longest duration of symptoms (5.3 months) was recorded in the BT group, whereas it was somewhat shorter in 
the $\mathrm{T}$ and $\mathrm{B}$ groups (4.7 months in group $\mathrm{T}$ and 3.9 months in group B). The ratio of ischemic to non-ischemic types of occlusion is shown in Table 1. Ischemic type was considered if the capillary occlusion area was greater than 10 disc diameters as documented on fluorescein angiography.

A secondary outcome of the study was the change in VA. The distribution across the groups is shown in Figures 2, 3 and 4.

Distribution of VA varied among the groups (Kruskal-Wallis test for independent samples, $\mathrm{p}=0.024)$. Bevacizumab and the combination of both medications were more efficient than triamcinolone alone, while the $\mathrm{B}$ and BT groups did not differ significantly, although a more obvious VA improvement was recorded in BT group. The qualitative shift in VA should be considered since BT group had the lowest initial VA and highest CMT (Fig. 5).

The VA was stable only in BT group, i.e. there was no negative shift; in T group, initial VA worsened in $60 \%$ of patients and therefore the most negative shift was recorded.

The primary outcome was the change in CMT. All three groups of patients had a significant decrease in CMT (Fig. 6). The combination of both medications was more efficient than bevacizumab $(\mathrm{p}=0.022)$. However, there was no statistically significant difference between triamcinolone and combination therapy $(\mathrm{p}=0.344)$. Group BT had the largest decrease in CMT. The initial average CMT was $325 \mu$ in group B, $506 \mu$ in group T, and $620 \mu$ in group BT. Following the third visit, the values were $316 \mu$ in group $B, 351 \mu$ in group T, and $397 \mu$ in group BT. The average initial CMT was $619 \mu$ in the ischemic type and $421 \mu$ in the non-ischemic type. These values were statistically significant $(\mathrm{p}=0.023)$. The CMT changes across the groups varied significantly $(\mathrm{p}=0.026$, Kruskal-Wallis test for independent samples).

Statistical analysis of the paired samples confirmed that the combination of medications was more efficient than bevacizumab while no difference was observed between triamcinolone and combination of medications regardless of better CMT improvement in BT group.

Another outcome was the effect of treatment on IOP. No significant IOP elevation or difference in IOP values across the groups was found (Fig. 7).

The highest IOP values did not exceed $27 \mathrm{~mm} \mathrm{Hg}$. No statistically significant difference was observed in
IOP values between the groups $\mathrm{BT}$ and $\mathrm{B}$. The IOP was $10-23 \mathrm{~mm} \mathrm{Hg}$ in group $\mathrm{B}, 8-26 \mathrm{~mm} \mathrm{Hg}$ in group $\mathrm{T}$, and $10-22 \mathrm{~mm} \mathrm{Hg}$ in group BT. The IOP changes across the groups were equally distributed $(p=0.716$, Kruskal-Wallis test for independent samples).

Patient age did not influence VA ( $\mathrm{p}=0.684), \mathrm{CMT}$ $(\mathrm{p}=0.701)$ or IOP $(\mathrm{p}=0.749)$. The average number of intravitreal injections was 3 in group B, 2 in group T, and 2 in group BT.

\section{Discussion}

Better initial VA, younger age and shorter duration of symptoms were recognized as positive predictive factors for functional improvement in BRVO 9 . In previous reports, $75 \%$ of patients with CRVO were refractory to treatment ${ }^{7}$. In our study, patients did not receive intravitreal therapy (anti-VEGF or corticosteroids) or laser treatment prior to enrolment in the study. Favorable response to combination therapy despite lower initial VA and higher CMT could be due to the residual potential of the photoreceptors, which are not irreversibly damaged by ischemia. A large proportion of patients had cataract at baseline $(63.6 \%$ in group B, $69.2 \%$ in group $\mathrm{T}$, and $76.5 \%$ in group BT), which contributed to the reduced VA recorded. However, none of the patients required cataract surgery during the follow up.

According to some authors, lower CMT and younger age are positive prognostic factors in $\mathrm{CRVO}^{10,11}$. Their study, though, lacks assessment of the perfusion status, which significantly affects the outcome and prognosis. The ischemic type of occlusion involves a more extensive area of capillary occlusion (i.e. over 10 disc diameter) and carries a graver prognosis ${ }^{12}$. In some cases, the degree of ischemia increases over time and it is responsible for 'conversion' of non-ischemic to ischemic type of occlusion ${ }^{13}$. Approximately one-third of CRVO patients cross from non-ischemic to ischemic type within a year ${ }^{14}$. The degree of retinal ischemia is therefore one of the most important prognostic factors for visual outcome in these patients. The BRAVO and CRUISE data suggest better visual outcome if there is no delay in starting treatment ${ }^{15}$. It is assumed that there is a larger extent of undamaged photoreceptors, as well as reversible ischemia in the early course of illness, which is susceptible to intravitreal anti-VEGF therapy. Ac- 
cording to the literature, higher macular thickness values indicate retinal ischemia ${ }^{16}$, which was also confirmed in our study. Better efficacy of the combined treatment suggests a more potent action of bevacizum$\mathrm{ab}$ and triamcinolone on lowering CMT and demands further studies. Considering IOP elevation, there was no significant elevation or changes of IOP across the groups or within any group of patients. The prevalence of secondary ocular hypertension or glaucoma after intravitreal triamcinolone acetonide (IVTA) administration varies from $40.4 \%$ to $53.3 \%{ }^{17}$. There was no significant IOP elevation in the BT and B groups, which could be attributed to the lower dose of corticosteroids (1 mg IVTA) used in the combined treatment. This confirms that the lower dose of corticosteroids ( $1 \mathrm{mg}$ IVTA) is efficient in treating macular edema secondary to RVO, with fewer complications compared to the usually administered dose of $4 \mathrm{mg}$ IVTA $^{18}$. No signs of intraocular inflammation or infection were noted among patients. Only one group $\mathrm{T}$ patient with ischemic CRVO developed neovascular glaucoma and that patient had primary open-angle glaucoma as a known risk factor at the time of enrolment in the study. Otherwise, none of the patients developed neovascularization of the iris, disc or retina. This confirmed a good safety profile of the combined treatment, which mandates validation through future studies on a larger sample of patients and longer follow up period. Macular thickness over $250 \mu$ was used as a reapplication criterion. The number of applications was lower in the BT group, which confirmed higher efficiency and lower economic burden of combined therapeutic approach. The reference books offer equivocal data on the number of applications. In the study by Hou et al. ${ }^{18}$, which compared the efficacy of intravitreal bevacizumab and IVTA in macular edema after RVO, the mean number of applications was 1.2 of IVTA and 3.83 of bevacizumab after one-year follow up (148.43 \pm 130.53 days). The dose of IVTA was $4 \mathrm{mg}$; hence, the lower number of applications could have been related to the higher dose of the medication, while the safety profile and IOP changes were better in our study. Another study assessed the efficacy of bevacizumab on the same model of the disease and has reported the mean of 8 applications during one-year follow up ${ }^{20}$. This could be due to a shorter interval of 4 weeks between applications as compared to 6-week regimen used in our study. The fewer number of ap- plications in the BT group in comparison to the results of other studies investigating the efficacy of IVTA in macular edema after $\mathrm{RVO}^{21}$ confirmed the hypothesis of an additive effect of the combination of both drugs. It has to be noted that the initial macular thickness according to groups was $\mathrm{B}=325 \mu \mathrm{m}, \mathrm{T}=506 \mu \mathrm{m}$, and $\mathrm{BT}=620 \mu \mathrm{m}$. The final macular thickness which was measured after 12 months was on average $B=316 \mu \mathrm{m}$, $\mathrm{T}=351 \mu \mathrm{m}$, and BT $=396 \mu \mathrm{m}$. The difference was statistically significant between the bevacizumab and combination groups $(p=0.022)$, which confirmed the more potent action of the combination of both drugs. Most of the patients did not have complete regression of macular edema, which was reflected in the mean CMT after the third visit. In spite of this, there was certain VA improvement in the B and BT groups. This is in concordance with the results from the reference books and suggests that there are other factors that cause vascular leakage and residual edema other than $\mathrm{VEGF}^{22}$. This hypothesis is confirmed by the reports of targeted panretinal photocoagulation of the ischemic retinal areas reducing rebound macular edema ${ }^{23,24}$.

In conclusion, our study showed that combined treatment with bevacizumab and triamcinolone for macular edema secondary to RVO may represent a novel therapeutic option when compared to a single treatment option. It implies a lower rate of adverse events and less frequent intravitreal administration of drug. However, future studies should include a larger number of patients with BRVO to confirm these results and allow for better harmonization among groups. Other registered intraocular medications approved for this indication should have advantage but we find that this represents a reasonable therapeutic option which should be considered if they are not available due to medico-economic issues. This study also confirmed the need of novel combination treatment options to fight macular edema more efficiently.

\section{References}

1. Bearelly S, Fekrat S. Controversy in the management of retinal venous occlusive disease. Int Ophthalmol Clin. 2004;44(4): 85-102. doi: 10.1097/00004397-200404440-00008

2. Laouri M, Chen E, Looman M, Gallagher M. The burden of disease of retinal vein occlusion: review of the literature. Eye (Lond). 2011;25(8):981-8. doi: 10.1038/eye.2011.92

3. Matsumoto Y, Bailey Freund K, Peiretti E, Cooney MJ, Ferrara DC, Yanuzzi LA. Rebound macular edema following bevaci- 
zumab (Avastin) therapy for retinal venous occlusive disease. Retina. 2007;27(4):426-31. doi: 10.1097/IAE.0b013e3180 $4 \mathrm{a} 7 \mathrm{af} 2$

4. Turello, M., Pasca S, Daminato R, Dello Russo P, Giacomello R, Venturelli U, Barillari G. Retinal vein occlusion: evaluation of "classic" and "emerging" risk factors and treatment. J Thromb Thrombolysis. 2010;29(4):459-64. doi: 10.1007/s11239-0090384-5

5. Pieramici DJ, Rabena MD. Anti-VEGF therapy: comparison of current and future agents. Eye (Lond). 2008;22(10):1330-6. doi: 10.1038/eye.2008.88

6. Jermak, CM, Dellacroce JT, Heffez J, Peyman GA. Triamcinolone acetonide in ocular therapeutics. Surv Ophthalmol. 2007;52(5):503-22. doi: 10.1016/j.survophthal.2007.06.004. PMID: 17719372

7. Ehrlich R, Ciulla TA, Moss AM, Harris A. Combined treatment of intravitreal bevacizumab and intravitreal triamcinolone in patients with retinal vein occlusion: 6 months of followup. Graefes Arch Clin Exp Ophthalmol. 2010;248(3):375-80. doi: 10.1007/s00417-009-1211-6

8. Scott IU, Ip MS, VanVeldhuisen PC, Oden NL, Blodi BA, Fisher M, Chan CK, Gonzalez VH, Singerman LJ, Tolentino M. A randomized trial comparing the efficacy and safety of intravitreal triamcinolone with standard care to treat vision loss associated with macular edema secondary to branch retinal vein occlusion: the Standard Care vs Corticosteroid for Retinal Vein Occlusion (SCORE) study report 6. Arch Ophthalmol. 2009;127(9):1115-28. doi:10.1001/archophthalmol.2009.233

9. Jaissle, GB, Szurman P, Feltgen N, Spitzer B, Pielen A, Rehak M, Spital G, Heimann H, Meyer CH; Retinal Vein Occlusion Study Group. Predictive factors for functional improvement after intravitreal bevacizumab therapy for macular edema due to branch retinal vein occlusion. Graefes Arch Clin Exp Ophthalmol. 2011;249(2):183-92. doi: 10.1007/s00417-010-1470-2

10. Ach T, Hoeh AE, Schaal KB, Scheuerle AF, Dithmar S. Predictive factors for changes in macular edema in intravitreal bevacizumab therapy of retinal vein occlusion. Graefes Arch Clin Exp Ophthalmol. 2010;248(2):155-9. doi: 10.1007/ s00417-009-1167-6

11. Hayreh SS, Podhajsky PA, Zimmerman MB. Natural history of visual outcome in central retinal vein occlusion. Ophthalmology. 2011;118(1):119-133e1-2. doi: 10.1016/j.ophtha.2010 .04 .019

12. McIntosh RL, Rogers SL, Lim L, Cheung N, Wang JJ, Mitchell P, Kowalski JW, Nguyen HP, Wong TY. Natural history of central retinal vein occlusion: an evidence-based systematic review. Ophthalmology. 2010;117(6):1113-1123e15. doi: 10.1016/j.ophtha.2010.01.060

13. Jaulim A, Ahmed B, Khanam T, Chatziralli IP. Branch retinal vein occlusion: epidemiology, pathogenesis, risk factors, clini- cal features, diagnosis, and complications. An update of the literature. Retina. 2013;33(5):901-10. doi: 10.1097/IAE. 0b013e3182870c15

14. Varma R, Bressler NM, Suñer I, Lee P, Dolan CM, Ward J, Colman S, Rubio RG; BRAVO and CRUISE Study Groups. Improved vision-related function after ranibizumab for macular edema after retinal vein occlusion: results from the BRAVO and CRUISE trials. Ophthalmology. 2012;119(10):2108-18. doi: 10.1016/j.ophtha.2012.05.017

15. Bhisitkul RB, Campochiaro PA, Shapiro H, Rubio RG. Predictive value in retinal vein occlusions of early versus late or incomplete ranibizumab response defined by optical coherence tomography. Ophthalmology. 2013;120(5):1057-63. doi: 10.1016/j.ophtha.2012.11.011

16. Gillies MC, Simpson JM, Billson FA, Luo W, Penfold P, Chua W, Mitchell P, Zhu M, Hunyor AB. Safety of an intravitreal injection of triamcinolone: results from a randomized clinical trial. Arch Ophthalmol. 2004;122(3):336-40. doi: 10.1001/archopht.122.3.336

17. Cekic O, Chang S, Tseng JJ, Barile GR, Weissman H, Del Priore LV, Schiff WM, Weiss M, Klancnik JM Jr. Intravitreal triamcinolone treatment for macular edema associated with central retinal vein occlusion and hemiretinal vein occlusion. Retina. 2005;25(7):846-50. doi: 10.1097/00006982-2005100 00-00005

18. Hou J, Tao Y, Jiang Y, Li X, Gao L. Intravitreal bevacizumab versus triamcinolone acetonide for macular edema due to branch retinal vein occlusion: a matched study. Chin Med J (Engl). 2009;122(22):2695-9. DOI: 10.3760/cma.j.issn.0366 $-6999.2009 .22 .004$

19. Rosenfeld PJ, Fung AE, Puliafito CA. Optical coherence tomography findings after an intravitreal injection of bevacizumab (Avastin) for macular edema from central retinal vein occlusion. Ophthalmic Surg Lasers Imaging. 2005;36(4):336-9

20. Lim JW, Na KI. A comparative study between intravitreal triamcinolone and bevacizumab for macular edema due to central retinal vein occlusion with poor vision. Indian J Ophthalmol. 2011;59(2):93-6. doi 10.4103/0301-4738.77008

21. Spaide RF. Peripheral areas of nonperfusion in treated central retinal vein occlusion as imaged by wide-field fluorescein angiography. Retina. 2011;31(5):829-37. doi: 10.1097/IAE. 0b013e31820c841e

22. Arnarsson A, Stefansson E. Laser treatment and the mechanism of edema reduction in branch retinal vein occlusion. Invest Ophthalmol Vis Sci. 2000;41(3):877-9

23. Tomić M, Vrabec R, Poljičanin T, Ljubić S, Duvnjak, L. Diabetic macular edema: traditional and novel treatment. Acta Clin Croat. 2017;56:124-32. doi 10.20471/acc.2017.56.01.18 
Sažetak

\section{KOMBINIRANO LIJEČENJE MAKULARNOG EDEMA UZROKOVANOG OKLUZIJOM MREŽNIČNE VENE BEVACIZUMABOM I TRIAMCINOLON ACETONIDOM}

\section{Vinković, D. Bosnar, E. Tedeschi Reiner, G. De Salvo i S. Matić}

Cilj rada bio je utvrditi učinkovitost kombinirane intravitrealne terapije bevacizumabom i triamcinolonom kod makularnog edema nastalog kao posljedica okluzije mrežnične vene. Prospektivno randomizirano ispitivanje provedeno je na Odjelu za očne bolesti Kliničkoga bolničkog centra Osijek. U ispitivanje je bio uključen 51 ispitanik, koji su podijeljeni u tri skupine ovisno o vrsti lijeka koji su primali. Bolesnici u prvoj skupini primali su $1,25 \mathrm{mg}$ bevacizumaba intravitrealno, druga skupina ispitanika je primala $1 \mathrm{mg}$ triamcinolona intravitrealno, a treća skupina je primala kombinaciju $1,25 \mathrm{mg}$ bevacizumaba i $1 \mathrm{mg}$ triamcinolona intravitrealno $\mathrm{u}$ istom posjetu. Tijekom razdoblja praćenja promatrane su promjene u centralnoj makularnoj debljini, vidnoj oštrini, kao i vrijednosti intraokularnog tlaka. Fluoresceinska angiografija primijenjena je za procjenu perfuzijskog statusa retine. Skupina koja je primila kombiniranu terapiju s oba lijeka imala je bolji ishod u vidu smanjenja makularne debljine. Nije bilo značajnijeg povišenja očnog tlaka unutar skupina, kao ni usporedbom među skupinama. U skupini ispitanika koji su primili kombinaciju oba lijeka zabilježen je pozitivan trend u oporavku vidne oštrine, iako su imali najniže ulazne vrijednosti vidne oštrine, najveću vrijednost centralne makularne debljine mjerenu optičkom koherentnom tomografijom i najduže prosječno trajanje okluzije u odnosu na ostale skupine ispitanika. Zaključno, smanjenje broja injekcija kod primjene kombinacije oba lijeka predstavlja ekonomičniji pristup liječenju okluzije mrežnične vene, a također djeluje potentnije na sniženje centralne makularne debljine u odnosu na pojedinačnu primjenu svakog lijeka.

Ključne riječi: Okluzija mrežnične vene; Makularni edem; Intravitrealna primjena; Triamcinolon; Bevacizumab 